\title{
A Tale of Two Cities:
}

\section{Woman and City in "The Age of Innocence" and "The Song of Everlasting Sorrow"}

\author{
Shiyu Zhou \\ School of Foreign Languages \\ China University of Geosciences (Wuhan) \\ Wuhan, China \\ dakejuinf@163.com
}

\begin{abstract}
Edith Wharton's The Age of Innocence and Wang Anyi's The Song of Everlasting Sorrow are regarded as masterpieces in their respective countries and arouse many critics' interest. This ess ay explores how the two heroines, Wang Qiyao and Ellen, are closely connected with the cities they live in. Although the two novels both touch upon the issue of woman and city, the heroines illustrate different ways of cultivating inner strength to survive in a chaotic era. Ellen's way of finding security within herself is by keeping order and solidarity in Old New York while Wang Qiyao uses material wisdom and skill to build a shelter.
\end{abstract}

Keywords-The Age of Innocence; The Song of Everlasting Sorrow; comparative study; feminism; city

\section{INTRODUCTION}

As one of the most influential American female writers in the 20th century, Edith Wharton has written more than 40 books, covering many genres. Among those, The Age of Innocence, the Pulitzer Prize Winner, is widely regarded as her greatest literary accomplishment.

Since its publication, The Age of Innocence has aroused great interest among critics. As Wharton always focus on upper-class life and the reason why she writes this novel is that the disastrous First World War leads her to miss the traditions in old New York, a lot of papers are about this book's background-a gentle New York threatened by rising new-riches. Mary Suzanne Schriber comments on Wharton's nostalgia for the past: "The Age of Innocence is a complaint against an insidious tendency to substitute tradition for the direct apprehension of life" [9]. In his Introduction to The Age of Innocence, R.W.B. Lewis calls the novel "Wharton's reminiscent and shrewdly ambivalent survey of her own old New York” [5].

As feminism becomes more and more popular since the 1970s, a number of literary critics start to reconsider The Age of Innocence from feminist perspective. In the well-known biography on Edith Wharton, Lewis says that her work is a mirror of female experience in the first decades of 20th century America and draws readers' attention to the "entrapment, betrayal and exclusion” women suffer [4]. Elizabeth Ammons acknowledges Wharton's attack on the patriarchal society. She

Supported by "the Fundamental Research Funds for the Central Universities of CUG (Wuhan)” CUGW170814 also suggests that Ellen is the representative of "New Woman" who is different from May-the representative of perfect womanhood [1].

Like Edith Wharton, Wang Anyi is also an influential female writer who is one of the most prolific, dynamic and imaginative writers on the contemporary Chinese literary scene. Among her rich body of work, The Song of Everlasting Sorrow stands out as her crowning literary achievement and inspires numerous critics' interest. Being called an epic of Shanghai, the novel revives the Shanghai style of art and literature. As a result, many attribute its success to old Shanghai nostalgia. In Xiaobing Tang's view, "historical melancholy is the origin and content of Wang Anyi's recent tales of sorrow" [13]. The Song of Everlasting Sorrow expresses the author's consciousness of the approaching end of a century and her utopian longings for the past. Xudong Zhang claims that as a sentimental intellectual, Wang Anyi considers nostalgia as a mythical key in Chinese history and uses it as a response to global ideology [14].

The same as Ellen in The Age of Innocence, the heroine of The Song of Everlasting Sorrow-Wang Qiyao is a beautiful woman. Quite a few critics analyze her from feminist point of view. Sai Niya regards Wang Qiyao as a product of the consumerist culture who has neither love nor soul [8]. Chen $\mathrm{Li}$ claims that the ending clearly shows Wang Anyi's compromise with traditional values [2]. Different from their arguments, $\mathrm{Li}$ Shuxia states that Wang Qiyao is an independent, strong and admirable woman who faces the vicissitudes in life bravely and calmly; while the males in the book are coward and powerless. By contrasting Wang Qiyao to the males, Wang Anyi emphasizes females' strength [6].

According to my research, there are a large number of essays about The Age of Innocence and The Song of Everlasting Sorrow respectively. But very few papers comment on the comparison between the two novels. The two heroines, Wang Qiyao and Ellen, are closely connected with the cities they live in. Being placed at turbulent ages when old orders are collapsing, their life stories are deeply embedded in the ups and downs of history. Although the two novels both touch upon the issue of woman and city, they express the authors' different 
feminist thoughts. This essay explores how Ellen and Wang Qiyao draw strength from their inner hearts in different ways.

\section{ELLEN AND NEW YORK}

Edith Wharton writes The Age of Innocence in 1919 while still suffering from the traumatic effects of the World War I . It is understandable that the novel is filled with remembrance for the past New York. In A Backward Glance, Wharton admits that 1914 had torn down the "old framework" of the society of her youth and she is responsible for the reconstruction [11]. As a result, the reason why she writes The Age of Innocence is that she "found a momentary escape in going back to my childish memories of a long-vanished America” [11]. Her commemoration draws her to New York of the sixties and seventies when the city starts to feel the first vibrations of change.

As an outsider, Ellen's relationship with New York indicates the conflict between the old aristocracy and the new rich. This is an age when traditions are threatened by bourgeois values. The old order is dying and the new order is taking shape. The old New York represented by the Luydens, Mingotts and Newlands is conscious of the increasing impact of the new social stratification represented by Beaufort who is a wealthy businessman with a mysterious origin. "With old Catherine Spicer ruling one end of the Fifth Avenue, and Julius Beaufort the other, you couldn't expect the old traditions to last much longer" [12]. Both Mrs. Archer and Mr. Jackson, the guidance for the "form" in the upper class, lament several times that New York is very much changed. Beaufort opens the door to the Old New York with his money and lavish lifestyle. "for over twenty years now people has said they were 'going to the Beauforts' with the same tone of security as if they were going to Mrs. Manson Mingott's" [12]. Though the old class can not resist the temptation of the luxurious parties hosted by the new comers, they despise those people's low origin. The gap between different classes is irremovable. Mrs. Archer's claim, "we all have our pet common people", clearly shows the aristocracy's attitude towards the new rich [11]. Lawrence Leffert looks down upon Beaufort and makes such a prophecy, "if things go on at this rate, our children will be marrying Beaufort's bastards" [12]. The upper class has to accept the new rich because their wealth and vigor may rejuvenate the decaying aristocrats. As old Mrs. Mingott says, "we need new money and new blood" [12]. But once they fail in business, the new comers will be banished from the society mercilessly. Even Mrs. Beaufort, a member of the aristocracy, is sacrificed since the honor of the community is the most important. In order to keep dignity, the old class makes great efforts to build a wall between its members and the new comers. As a result, Ellen's association with Beaufort and Mrs. Struthers challenges old manners and makes her family humiliated. Although Ellen is a member of the Mingotts, the upper-class society classifies her into the group of vulgar intruders and finally expels her from New York. The farewell dinner for her is "the tribal rally around a kinswoman about to be eliminated from the tribe" [12].

As a foreigner, Ellen's relationship with New York indicates the conflict between European and American culture. In the eyes of the American aristocracies, Europeans are often weird and radical. Due to her unusual dress and behavior, Ellen is described as a bohemian. The traditional society often ascribes her "vulgarity" to foreignness. For instance, Archer imagines that adultery is not uncommon in European communities.

Rich and idle and ornamental societies must produce many more such situations; and there might even be one in which a woman naturally sensitive and aloof would yet, from the force of circumstances, from sheer defenselessness and loneliness, be drawn into a tie inexcusable by conventional standards. [12]

When Mr. Jackson tells Mrs. Archer that Ellen walks up Fifth Avenue with Beaufort by the whole of New York, her first reaction is that foreigners know nothing about the sense of delicacy. After hearing that Ellen goes to Mrs. Lemuel Struthers's party with the Duke, the astonished Mrs. Archer tries to find an excuse for her behavior: "the society abroad is different...that people are not as particular, and that Madame Olenska may not have realized how we feel about such things" [12]. Besides, Beaufort's bank default reinforces foreigners' potential threat. The old New York is afraid of European influence and holds the line against the immigrants. As a result, Ellen's Eastern European marriage and her association with the foreigners and the radicals, like her neighbor Ned Winsett, offend the orthodox culture. Ellen's danger arises from her potentially polluting influence which is related to decadent European culture.

The old New York can not accept Ellen just as it can not willingly accept the new rich and European culture. To the upper-class, Ellen epitomizes unpleasant things: foreigners, artists and sexual and financial nonconformity - which seem to menace the body of the old New York [2]. In such a rigid society, Ellen's isolation and even expulsion seem inevitable.

\section{WANG QIYAO AND SHANGHAI}

Although The Song of Everlasting Sorrow is about a woman's life story, it is widely regarded as a Shanghai epic. In Rebuilding the Ivory Tower, Wang Anyi says that Wang Qiyao is just a spokeswoman of Shanghai and what she really wants to write about is the story of a city. The author tries to create a story of Shanghai, including its streets, its atmosphere and its spirit. In order to achieve her aim, Wang Anyi uses the details of a woman's life to show how Shanghai changes in forty years.

The relationship between women and city is delicately described at the beginning of the novel. Through detailed portrayal about longtang, gossip, the young lady's bedchamber, pigeons and Wang Qiyao, Wang Anyi makes it clear that the focus of the book is the most ordinary people living in longtang. As the typical daughter of longtang, Wang Qiyao is undoubtedly the epitome of Shanghai culture.

Shanghai's splendor is actually a kind of feminine grace; the scent carried by the wind is a woman's perfume...The shadows of the French parasol trees seem to carry a womanly aura, as do the oleanders and lilacs in the courtyards - the most feminine of flowers...The city is like one big goddess, wearing clothes plumbed with rainbows, scattering silver and gold across the sky. The colored clouds are the sleeves of her gown. [10] 
In this paragraph, Shanghai is like a graceful woman who cares about her cheongsam and coffee. From a fishing village to Paris of the East, Shanghai is always beautiful and brilliant. The female in this city, represented by Wang Qiyao, is the symbol of its beauty. Different from the paradise for adventurers in Midnight, Shanghai is feminine in The Song of Everlasting Sorrow. The political upheavals and violent strikes which fill male writers' Shanghai are replaced by domestic details such as lace of curtains. Historical events are just vague background while clothes and food are the core of life.

Although the author does not directly delineate historical events, it is the city's modern history that forms the backbone of the tale. There are hints at time in every turning point of the heroine's life. The story starts in 1946 when Shanghai is a sleepless city. In this modern metropolis, Wang Qiyao meets the apex of her life: winning the third place in Miss Shanghai Contest. Her charm belongs to the city's glamour. Then she becomes Director Li's mistress in 1948 when the Liberation is on the way. In the 50s and 60s, she hides in Peace Lane and lives a peaceful life when Shanghai is experiencing upheavals. Though she is still young, her beauty is fading. The city's splendor is taken place by uniformity, as well. In the 80s, fashion comes back and she once again becomes the centre of parties. But she is out of date and only serves to satisfy people's curiosity about the past time. Shanghai is also transformed into an industrial city with crumbling longtang and polluted rivers. Wang Qiyao's death is inevitable since she is like the old clothes which are from the wrong era. It suggests an end to the age of old Shanghai, an end to any vestige it used to possess.

\section{IV. “A SLIPPERY PyRAMID” VS A FADING SHANGHAi UNDER OVERWHELMING FORCES}

As discussed above, New York is a small slippery pyramid which constantly attempts to keep the old order. Generally speaking, there are two ways to keep the society stable: expulsion and replication. The upper-class's attitude towards Ellen and Beaufort are typical examples of the former method. In The Age of Innocence, cultural conformity can be seen everywhere. In domestic space, we frequently see how individual choice is determined by the family interest and how children grow into copies of parents. For instance, Archer feels several times that May is more and more like her mother. And May dies content, leaving a daughter of whom she is as sure as of her own self. In public scenes, we also see heritage in every corner. The parties and operas repeat day after day, season after season. "Even an archery match produces a diamond arrow to be passed on to the eldest daughter" [3].

Throughout the novel, Wharton focuses on the upper class in New York - the top of the pyramid. As a member of this clan, Wharton misses the old order though she criticizes its suffocating rituals. Harold Bloom claims that she emphasizes an idea of order. The old order at least is an order and she is horrified at the postwar United States. Knights also comments that "she pursues old traces...reassembling them even while they vanish like the visions of the night" [3]. It explains why she can not give Archer a happy ending with Ellen. The deeply held fear of chaos makes her expel Ellen who threatens the social structure. To write otherwise may suggest a collapse of the pyramid.

Similar to The Age of Innocence, The Song of Everlasting Sorrow is also about a woman and a city. However, different from Wharton's emphasis on the aristocratic class, Wang Anyi pays much attention to the most commonplace life. According to her, the essence of a city is the ordinary people who strive for better. For example, both two authors describe food, but their purposes are distinct.

The Roman punch made all the difference; not in itself but by its manifold implications - since it signifies either canvasbacks or terrapin, two soups, a hot and a cold sweet, full décolletage with short sleeves, and guests of a proportionate importance. [12]

What a lovely scene it was - the snow drifting outside, the stove burning inside. They thought up all kinds of delightful things they could do with the stove, roasting Korean dried fish, baking pastries, scalding thinly sliced mutton in a pot of water, boiling noodles, and so forth. Gathered around the stove, they chatted, ate, and drank. [10]

In the former paragraph, food is a sign of form and social position. Different class eats different food. Wharton uses food to show the importance of social norms and the clear cut among different stratifications. By comparison, the second paragraph delineates a warm gathering. Although the outside world is chaotic, the ordinary life still goes on in the same way and the common people still enjoys homely happiness. The true content of life is meticulously collected from the quotidian concreteness, such as food.

Besides, Wharton tries to keep everything in order in The Age of Innocence, while the life and city in The Song of Everlasting Sorrow is constantly changing. Wang Anyi embeds historical upheavals into Wang Qiyao's life and shows that how Shanghai groans under overwhelming forces. In the novel, the ordinary life is closely related with history. Facing this power, both Wang Qiyao and Shanghai can not control their fate. As the woman gradually loses her beauty, Shanghai declines from its colonial splendor of the 1940s to an industrial city. Wang Qiyao expresses her powerlessness towards fate: "It looks like winning and losing are predestined. One cannot force the hand of fate". Even at the peak of life, she still feels the overwhelming force: "however glorious life might be, it will make the rounds and go home" [10]. Not only the common people but also Shanghai can not escape from history.

Both The Age of Innocence and The Song of Everlasting Sorrow tell a story about woman and city, but the heroines illustrate two different ways of cultivating inner strength to survive in a chaotic era. As a responsible, rational and self-dignified woman, Ellen contains Wharton's ideas about upper-class morality in Old New York. Ellen's way of finding security within herself is by keeping order and solidarity in Old New York. One of the qualities which Ellen admires New York most is solidarity. As a member of the upper-class, Wharton also regards 'family' as a very important foundation of New York. In the novel, her repeated lexicon of "clan" and "tribe" implies her own concern about the entity. 
In Wang Qiyao's case, she uses material wisdom and skill to build a shelter which protects her from the political deluge. It is this kind of wisdom that turns life into something really real. No matter how the outside world is, she only focuses on her everyday life. Even when the city is overwhelmed by revolutionary fervor and heat, she still indulges in food and tries to make life more livable because she believes that everything has a base and food and clothing is the core of life.

\section{CONCLUSION}

Both Ellen and Wang Qiyao, the respective heroines of Edith Wharton's The Age of Innocence and Wang Anyi's The Song of Everlasting Sorrow, are beauties who have great strength in their hearts. However, due to cultural and historical differences, their female consciousness originates from distinct points.

Although both novels talk about women and cities, their focuses are different. As a member of upper-class in Old New York, Ellen finds the importance of order and solidarity. Understanding the value of making sacrifice for the good of others, she possesses the morality which is the most important part in her ideal New York. The paradise is in neither her family nor Archer, but in her own heart. To some degree, Ellen's conflict with New York implies the aristocrats' hostility towards the rich and Europeans. She understands that one will achieve true maturity only when he/she accepts the conventions and values that shape him/her. By comparison, Wang Anyi embeds the rise and fall of her heroine within the waving folds of Shanghai's modern history. No matter how the outside world is, she only focuses on her everyday life. Her concentration on earthly happiness is similar to Lin Yutang's idea about Chinese humanism. According to him, the Chinese has a great capacity to enjoy the few things we own and "the true end of life lies in the enjoyment of a simple life, especially the family life” [7]. Only by a steadfast holding to life itself can we go through vicissitudes.
Both Ellen and Wang Qiyao can be seen as the representatives of the cities they live in turbulent eras, but they demonstrate different ways of facing vicissitudes. Ellen is a bunch of yellow roses blossoming in delicately decorated drawing-room; while Wang Qiyao is a vase of nameless flowerets on everyone's windowsills.

\section{REFERENCES}

[1] Ammons, Elizabeth. Edith Wharton's Argument with America. Athens: University of Georgia Press, 1980.

[2] Chen, Li. “The Dilemma in Wang An Yi's Writing”. Contemporary Writers Review. 4(2003):340-362. [In Chinese]

[3] Knights, Pamela. "Forms of Disembodiment: The Social Subject in The Age of Innocence.” Millicent, Bell. ed. The Cambridge Companion to Edith Wharton. London: Cambridge University Press, 1995.

[4] Lewis, R. W. B.. Edith Wharton: A Biography. New York: Harper\& Row, 1975.

[5] ---. Introduction to The Age of Innocence, by Edith Wharton. Beijing: Foreign Language Teaching and Research Press, 2005.

[6] Li, Shuxia. Studies on Wang An Yi's Fiction Writing. Qingdao: China Ccean University Press, 2008. [In Chinese]

[7] Lin, Yutang. My country and my people. New York: Reynal \& Hitchcock, 1935.

[8] Sai, Niya. "Misunderstandings on Wang An Yi’s FictionWriting”. Art and Literature. 1(2004):419-431. [In Chinese]

[9] Schriber, Mary Suzanne. "Convention in the Fiction of Edith Wharton.” Studies in American Fiction 11(1983).

[10] Wang, Anyi. The Song of Everlasting Sorrow: A Novel of Shanghai. Trans. Michael Berry and Susan Chan Egan. New York: Columbia University Press, 2008.

[11] Wharton, Edith. A Backward Glance. New York: Scribner, 1985.

[12] ---. The Age of Innocence. Beijing: China International Broadcasting Press, 2008.

[13] Xiaobing, Tang. "Melancholy against the Grain: Approaching Postmodernism in Wang Anyi's Tales of Sorrow." Boundary 24.2(1997):177-199.

[14] Xudong, Zhang. "Shanghai Image: Critical Iconography Minor Literature, and the Un-Making of a Modern Chinese Mythology.” New Literary History. 33(2002):137-169. 